\title{
Effects of magnolol on UVB-induced skin cancer development in mice and its possible mechanism of action
}

\author{
Chandeshwari Chilampalli', Ruth Guillermo ${ }^{1}$, Xiaoying Zhang ${ }^{2}$, Radhey S Kaushik ${ }^{3,4}$, Alan Young ${ }^{4}$, David Zeman ${ }^{4}$, \\ Michael B Hildreth ${ }^{3}$, Hesham Fahmy ${ }^{1}$ and Chandradhar Dwivedi ${ }^{*}$
}

\begin{abstract}
Background: Magnolol, a plant lignan isolated from the bark and seed cones of Magnolia officinalis, has been shown to have chemopreventive effects on chemically-induced skin cancer development. The objectives of this investigation are to study the anticarcinogenic effects of magnolol on UVB-induced skin tumor development in SKH-1 mice, a model relevant to humans, and determine the possible role of apoptosis and cell cycle arrest involved in the skin tumor development.
\end{abstract}

Methods: UVB-induced skin carcinogenesis model in SKH-1 mice was used for determining the preventive effects of magnolol on skin cancer development. Western blottings and flow cytometric analysis were used to study the effects of magnolol on apoptosis and cell cycle.

Results: Magnolol pretreated groups (30,60 $\mu$ g) before UVB treatments (30 mJ/ $\mathrm{cm}^{2}, 5$ days/week) resulted in 27$55 \%$ reduction in tumor multiplicity as compared to control group in SKH-1 mice. Magnolol pretreatment increased the cleavage of caspase-8 and poly-(-ADP-ribose) polymerase (PARP), increased the expression of p21, a cell cycle inhibitor, and decreased the expression of proteins involved in the G2/M phase of cell cycle in skin samples from $\mathrm{SKH}-1$ mice.

Treatment of A431 cells with magnolol decreased cell viability and cell proliferation in a concentration dependent manner. Magnolol induced G2/M phase cell cycle arrest in A431 cells at $12 \mathrm{~h}$ with a decreased expression of cell cycle proteins such as cyclin B1, cyclin A, CDK4, Cdc2 and simultaneous increase in the expression of Cip/p21, a cyclin-dependent kinase inhibitor. Magnolol induced apoptosis in vivo and in vitro with an increased cleavage of caspase- 8 and PARP. Phospho-signal transducers and activators of transcription 3 (Tyr ${ }^{705}$ ), B-Raf, p-MEK, and p-AKT were down-regulated, whereas phosphorylation of ERK was induced by magnolol in A431 cells.

Conclusions: Magnolol pretreatments prevent UVB-induced skin cancer development by enhancing apoptosis, causing cell cycle arrest at G2/M phase, and affecting various signaling pathways. Magnolol could be a potentially safe and potent anticarcinogenic agent against skin cancer.

\section{Background}

In the United States, human, non-melanoma skin cancers are most frequently diagnosed in Caucasians, accounting for over 3.5 million cases each year [1]. American Cancer Society estimates indicated 11,980 deaths from skin cancer in 2011 [2]. The major causative factor for skin

\footnotetext{
* Correspondence: Chandradhar.Dwivedi@sdstate.edu

'Department of Pharmaceutical Sciences, South Dakota State University, Brookings, SD 57007, USA

Full list of author information is available at the end of the article
}

cancer is UV radiation from sunlight $[3,4]$. Both experimental and epidemiological evidences suggest UVB is an important component of solar radiation that acts as a complete carcinogen by initiating and promoting skin cancer $[5,6]$. Estimates show that one among five Americans will develop skin cancer [7]. UV radiation, besides resulting in characteristic DNA damage, also causes tumor promotion by inducing various signal transduction pathways which can lead to distinct cellular responses including cell proliferation, transformation, and cell
C Biomed Central

(c) 2011 Chilampalli et al; licensee BioMed Central Ltd. This is an Open Access article distributed under the terms of the Creative Commons Attribution License (http://creativecommons.org/licenses/by/2.0), which permits unrestricted use, distribution, and reproduction in any medium, provided the original work is properly cited. 
death $[8,9]$. Mechanisms that suppress tumorigenesis involve the modulation of signal transduction pathways leading to arrest in the cell cycle progression or induction of apoptosis. It has been proposed that sunscreens alone are not sufficient in preventing skin cancer, thus there is a need for more effective ways to prevent this malignancy $[10,11]$. For this reason, chemoprevention of skin cancer by natural compounds has gained importance in recent years [12,13]. More than 1000 phytochemicals have shown chemopreventive effects against cancer [14-16], and one such phytochemical is magnolol, whose effects are investigated for the prevention of skin cancer in this study.

Magnolol and honokiol are phenolic compounds obtained from the bark and seed cones of Magnolia officinalis which has been used in traditional Chinese medicine. Recently, we have reported the chemopreventive effects of honokiol on UVB-induced skin cancer development in mice [17]. Honokiol and magnolol are isomers and share a number of biological properties. Studies have demonstrated that magnolol has multiple pharmacological properties such as antioxidant [18], anti-inflammatory [19], and central nervous system depressant effects [20]. It has been reported that magnolol delayed the formation of papillomas in mouse skin initiated by 7,12-dimethylbenz $(\alpha)$ anthracene (DMBA) and promoted by 12 -O-tetradecanoyl phorbol-13-acetate (TPA) [21].

For the first time, in this study, we reported the effects of magnolol on UVB-induced skin cancer development in SKH-1 mice. Since UVB induces squamous cell carcinoma in mice, the effects of magnolol on human epidermoid squamous cell carcinoma A431 cells were investigated to elucidate the possible mechanisms of action. The effects of magnolol were investigated on UVB-induced skin carcinogenesis in SKH-1 mice, a model relevant to human cancer where UVB acts as complete carcinogen. Loss of apoptosis and rapid cell proliferation are major factors responsible for tumorigenesis [22], therefore, the present study focuses on the effects of magnolol on apoptosis, cell survival pathways and cell cycle arrest.

Signal transduction and activators of transcription 3 (STAT 3) and mitogen-activated protein kinase (MAPK) signaling play a major role in apoptosis, proliferation, and tumor promotion $[23,24]$. Overactivity of the MAPK pathway has been shown to be involved in cancer promotion and development [25-27]. Therefore, we investigated the effects of magnolol on the modulation of STAT3 and MAPK signaling pathways.

\section{Methods}

\section{Reagents}

Magnolol was purchased from Nacalai tesque (Kyoto, Japan). Thiazolyl blue tetrazolium bromide (MTT) and other chemicals of analytical grade were purchased from Sigma Chemical Co. (St. Louis, MO). Cell proliferation ELISA kit was purchased from Roche Diagnostics GmbH (Mannheim, Germany). Vibrant Apoptosis Kit 2 and APO-BrdU TUNEL assay kit were purchased from Molecular Probes (Eugene, OR). The primary antibodies such as cleaved caspase-3, cleaved caspase-8, pSTAT3$\mathrm{Tyr}^{705}$, pSTAT3-Ser ${ }^{445}$, pMEK1/2, B-Raf and cleaved PARP were purchased from Cell Signaling Technology (Beverly, MA). Primary Antibodies such as Cdc25A, Cdc25B, Cdc25C, p-Cdc25C, CDK-2, CDK-4, Cyclin B1, Cyclin A, Cdc2p34, p-ERK1/2, p-AKT, PCNA, antimouse IgG horseradish peroxidase-linked and anti-rabbit IgG horseradish peroxidase-linked secondary antibodies were purchased from Santa Cruz Biotechnology (Santa Cruz, CA). Anti-Kip1/p27 antibody was purchased from BD-Pharmingen (San Diego, CA) and antiCip1/p21 antibody from Upstate Biotechnology (Lake Placid, NY).

\section{Cell culture}

Human epidermoid carcinoma A431 cells were purchased from American Type Culture Collection (Manassas, VA). A431 cells were cultured in DMEM supplemented with $10 \%$ heat inactivated fetal bovine serum, $100 \mathrm{unit} / \mathrm{ml}$ of penicillin and $100 \mathrm{ug} / \mathrm{ml}$ of streptomycin in a humidified atmosphere containing 95\% air and $5 \% \mathrm{CO}_{2}$ at $37^{\circ} \mathrm{C}$. For treatments of cell cultures, magnolol was dissolved in DMSO to make a $50 \mathrm{mM}$ stock solution, this stock solution was diluted in DMEM at different concentrations and was immediately used. In all assays the final concentration of DMSO in DMEM was $0.4 \%$.

\section{Animals}

Five to six week old female SKH-1 mice were purchased from Charles River Laboratories (Wilmington, MA, USA). Institutional Animal Care and Use Committee (IACUC) approvals were obtained for all experimental protocols. Mice were housed under climate-controlled environment with a 12 hours light/dark cycle and were provided with free access to food and water during the experiment.

\section{UVB Light Source}

Four FS-40-T-12 UVB lamps were used as UVB light source. UVB exposure dose was controlled by integrating dosimeters manufactured by Daavlin Corporation (Bryan, OH, USA).

\section{UVB-induced skin tumor development protocol}

Five to six weeks old female SKH-1 mice were randomly divided into four groups of 20 each. Carcinogenesis was initiated and promoted by UVB, dose $\left(30 \mathrm{~mJ} / \mathrm{cm}^{2}\right)$ for 5 
days a week (monday-friday). This is a dose close to the UVB human exposure causing cancer development [28]. Group 1 served as control and received $200 \mu 1$ of acetone, group 2, group 3 and group 4 received $30 \mu$ g, $45 \mu$ $\mathrm{g}$ and $60 \mu \mathrm{g}$ of magnolol in $200 \mu \mathrm{l}$ of acetone respectively. Treatments were administered topically one hour before UVB exposure. The experiment was carried out for 25 weeks. Tumor counts and body weights were recorded on weekly basis for 25 weeks. Results were analyzed for tumor incidence, multiplicity and area.

\section{Histopathological analysis of mice tumors}

Mice were euthanized by cervical dislocation at the end of the above mentioned protocol. Skin collected from five animals per group was fixed by immersion in $10 \%$ neutral buffered formalin for three days at room temperature. Fixed tissues were processed into paraffin-wax blocks, sectioned and stained with hematoxylin-eosin (HE) and then evaluated under light microscope.

\section{Effects of magnolol on tumor area in SKH-1 mice}

Tumor areas were quantified as described earlier [17,29] by using images from tumor bearing mice which were taken at the end of 25 weeks. By using Photoshop CS3 (Adobe systems, San Jose, CA, USA) tumor boundaries were determined and areas were measured by using Image-Pro Plus 5.1 (Media Cybernetics, Inc, Bethesda, MD, USA).

\section{MTT assay for cell viability}

A431 cells (9000 cells/well) were plated in 96 well plates. After $24 \mathrm{~h}$, cells were treated with different concentrations of magnolol $(75,100,125 \mu \mathrm{M})$ for $12 \mathrm{~h}, 24$ $\mathrm{h}$ and $48 \mathrm{~h}$, using cells treated with growth medium $0.4 \%$ DMSO as control. Cell viability was determined at the end of each treatment by using MTT assay as previously reported [30].

\section{BrdU assay for cell proliferation}

A431 cells (9000 cells/well) were plated in 96 well plates. After $24 \mathrm{~h}$, cells were treated with different concentrations of magnolol $(75,100,125 \mu \mathrm{M})$ or treated with growth medium $0.4 \%$ DMSO as control, for $48 \mathrm{~h}$. At the end of the treatment, Bromodeoxyuridine (BrdU) incorporation assay was carried out using ELISA kit (Roche Diagnostics, GmbH, Manheim, Germany) using manufacturer protocol as previously reported from our laboratory [30]. The experiment was repeated three times.

\section{Quantification of apoptosis by Annexin V/PI staining}

Apoptosis was quantified by using Vibrant Apoptosis Kit 2 (Molecular Probes) as previously reported from our laboratory [30]. A431 cells $\left(2 \times 10^{5}\right) /$ well were plated in six well plates and after $24 \mathrm{~h}$ were treated with magnolol $(100,150 \mu \mathrm{M})$ for $48 \mathrm{~h}$. Then cells were collected, washed and stained with annexin- $\mathrm{V}$ labeled with a fluorophore that binds to phosphatidylserine exposed on apoptotic cells. Also cells were treated with propidium iodide (PI) a DNA intercalator dye that stains dead cells. Samples were analyzed after staining with both dyes in BD FACScan flow cytometry and the percentages of apoptotic cells were evaluated using CellQuest software (BD Biosciences, San Jose, CA).

\section{Quantitation of DNA fragmentation by TUNEL assay}

Apo-BrdU TUNEL assay kit (Molecular Probes) was used to quantify the amount of DNA fragmentation in magnolol treated A431 cells by using manufacturer's protocol as previously reported [30]. Positive and negative control cells were run with each assay.

\section{Cell Cycle analysis}

Subconfluent A431 cells plated in six well plates were treated with different concentrations of magnolol (75, $100,125 \mu \mathrm{M})$ or control media for 12,24 and $48 \mathrm{~h}$. After each treatment, cells were harvested, washed and fixed in $70 \%$ ethanol in DPBS. Fixed cells were treated with $100 \mu \mathrm{l}$ of RNase A $(1 \mathrm{mg} / \mathrm{ml})$ for $30 \mathrm{~min}$ at $37^{\circ} \mathrm{C}$. After incubation, $900 \mu \mathrm{l}$ of staining buffer and $20 \mu \mathrm{l}$ of PI (Propidium iodide $1 \mathrm{mg} / \mathrm{ml}$ ) were added to each sample and incubated for $30 \mathrm{~min}$ in the dark. The samples were analyzed with BD FACScan flow cytometry (BD Biosciences, San Jose, CA) using Cell Quest Software (BD Biosciences, San Jose, CA) as previously reported $[31,32]$.

\section{Preparation of tissues and cell lysates for immunoblotting} Tissue samples: Mice were sacrificed by cervical dislocation, then treated skin was collected, fat from skin was removed by scalpel, and then skin was homogenized in $0.1 \mathrm{mM}$ Tris- $\mathrm{HCl} / 0.15 \mathrm{M} \mathrm{NaCl}$ (pH 7.4). The homogenate was filtered and centrifuged at $10000 \mathrm{~g}$ for $45 \mathrm{~min}$ in a Beckman J2-21 centrifuge (Brea, CA.), the obtained pellet was combined with $5 \%$ SDS, $0.5 \%$ leupeptin and pepstatin and 1\% PMSF, then was passed through a $25 \mathrm{G}$ needle and centrifuged at $13000 \mathrm{~g}$ for $20 \mathrm{~min}$, the obtained supernatant was heated for $5 \mathrm{~min}$ at $100^{\circ} \mathrm{C}$. Finally, protein concentrations were determined by BCA protein assay (Pierce, Rockford, IL), then separated by SDS-PAGE and analyzed by Western blot.

For A431 cell lysates, $1.5 \times 10^{6}$ cells were plated in $100 \mathrm{~mm}$ culture dish. Subconfluent A431 cells were treated with varying concentrations of magnolol (75, 100, $125 \mu \mathrm{M}$ ) and DMEM 0.4\% DMSO as control, for 24 and $48 \mathrm{~h}$. At the end of each treatment cells were lysed. 
Protein concentrations for tissues and cells' proteins were determined by BCA protein assay kit (Pierce, Rockford, IL) with albumin as standard.

The tissues or cells' proteins $(50 \mu \mathrm{g})$ were resolved by SDS-PAGE and were transferred onto nitrocellulose membranes. The membranes were probed with appropriate antibodies followed by secondary antibody and detection by ECL plus detection system (Amersham Biosciences, Piscataway, NJ). Equal protein loading is ensured by reprobing each membrane with $\beta$-actin antibody. Western blotting was repeated for 3-5 samples and representative bands from all replicated experiments are reported. Western blots were detected and quantified by using a UVB Biochem Gel Documentation system (UVP, Inc., Upland, CA) and this data were analyzed statistically.

\section{Statistical Analysis}

INSTAT software (Graph Pad, San Diego, CA) was used to analyze data. Chi square analysis was used for the data on tumor incidence. Analysis of variance followed by Tukey's test was used for tumor multiplicity and area, as well as for Western blots and for various in vitro assays. Significance in all experiments was considered at $p<0.05$. All values were expressed as mean \pm standard error.

\section{Results}

Effects of magnolol on weight gain and skin appearance Pretreatment of animals with magnolol at all doses did not have any effects on weight gain (data not shown) and skin appearance of mice indicating the safety of magnolol at these doses.

\section{Chemopreventive effects of magnolol on UVB-induced skin tumorigenesis}

The effects of magnolol pretreatment on the tumor incidence in SKH-1 mice are shown in Figure 1A. Tumor incidence was $100 \%$ in both the control and magnolol pretreated group $(45 \mu \mathrm{g})$ by the end of 25 weeks. Magnolol pretreatments with 30 and $60 \mu$ g per application delayed the appearance of tumors as compared to control and $45 \mu \mathrm{g}$ magnolol applications. The results showed that tumor incidence was significantly lower during 21-25 weeks $(p<0.05)$ in the magnolol pretreated groups (30 and $60 \mu \mathrm{g}$ ) as compared to control group. Overall, the magnolol pretreatments $(30,60 \mu \mathrm{g})$ decreased tumor incidence compared with control at the end of the experiment. Interestingly, $45 \mu \mathrm{g}$ application of magnolol did not have any significant effect on UVB-induced tumor incidence.

The effects of magnolol pretreatment on tumor multiplicity are shown in Figure 1B. Topical application of $30,45,60 \mu \mathrm{g}$ of magnolol prior to UVB treatments showed protection against skin tumor development in SKH-1 mice. We found that tumor multiplicity is significantly $(p<0.05)$ decreased in the magnolol pretreated groups $(30,60 \mu \mathrm{g})$ from 16 weeks to 25 weeks when compared to control group. At the end of the experiment, magnolol $30 \mu \mathrm{g}$ and $60 \mu \mathrm{g}$ pretreatments resulted in 27-55\% decrease in tumor multiplicity respectively. Interestingly, the $45 \mu \mathrm{g}$ application of magnolol had lesser effects than the $30 \mu \mathrm{g}$ application, similar to the results for tumor incidence.

The effects of magnolol pretreatment on the ratio of total tumor area to total back area are shown in Figure $1 C$. In the control and magnolol pretreated groups (30, 45 and $60 \mu \mathrm{g}$ ) the mean ratio of tumor area to total back area was $4.5 \%, 0.5 \%, 0.5 \%, 0.3 \%$ respectively, resulting in $87-93 \%$ reduction in tumor area with magnolol pretreatments compared to control. Unlike the data on tumor incidence and multiplicity, effects of $45 \mu \mathrm{g}$ application of magnolol had similar effects as 30 and $60 \mu \mathrm{g}$ applications. A representative picture showing gross appearance of the animals is shown in Figure 2.

The histopathological examination of the tumors after 25 weeks of treatments indicated that control and magnolol treated groups developed squamous cell carcinoma in the skin (Pictures not shown).

\section{Effects of magnolol on apoptotic proteins in SKH-1 mice} Epidermal lysates from mice skin of both control and magnolol pretreated groups were prepared at the end of the study. The effects of magnolol on caspase- 8 and PARP cleavage, key proteins in apoptosis, are shown in Figure 3A. Topical application of magnolol significantly $(p<0.05)$ increased the cleavage of caspase- 8 and PARP as compared to control.

\section{Effects of magnolol on cell cycle proteins in SKH-1 mice} Our studies on the effects of magnolol on human epidermoid carcinoma A431 cells indicated that magnolol caused cell cycle arrest at G2/M phase (results reported later in the manuscript). Therefore, we investigated various proteins involved in G2/M phase of the cell cycle in skin samples collected from the various experimental groups. The effects of magnolol on cell cycle proteins from skin of experimental mice are shown in Figure 3B. Pretreatment of magnolol decreased the expression of Cyclin B1, Cyclin A, CDK4 and $\mathrm{Cdc} 25 \mathrm{~B}$ but increased expression of $\mathrm{Cdc} 2$ and Cdc25A as compared to control. Topical application of magnolol to SKH-1 mice resulted in increased expression of the cell cycle inhibitor p21.

In order to further elucidate the mechanism of action of magnolol, in vitro effects of various concentrations of magnolol on human epidermoid carcinoma A431 cells were investigated. 

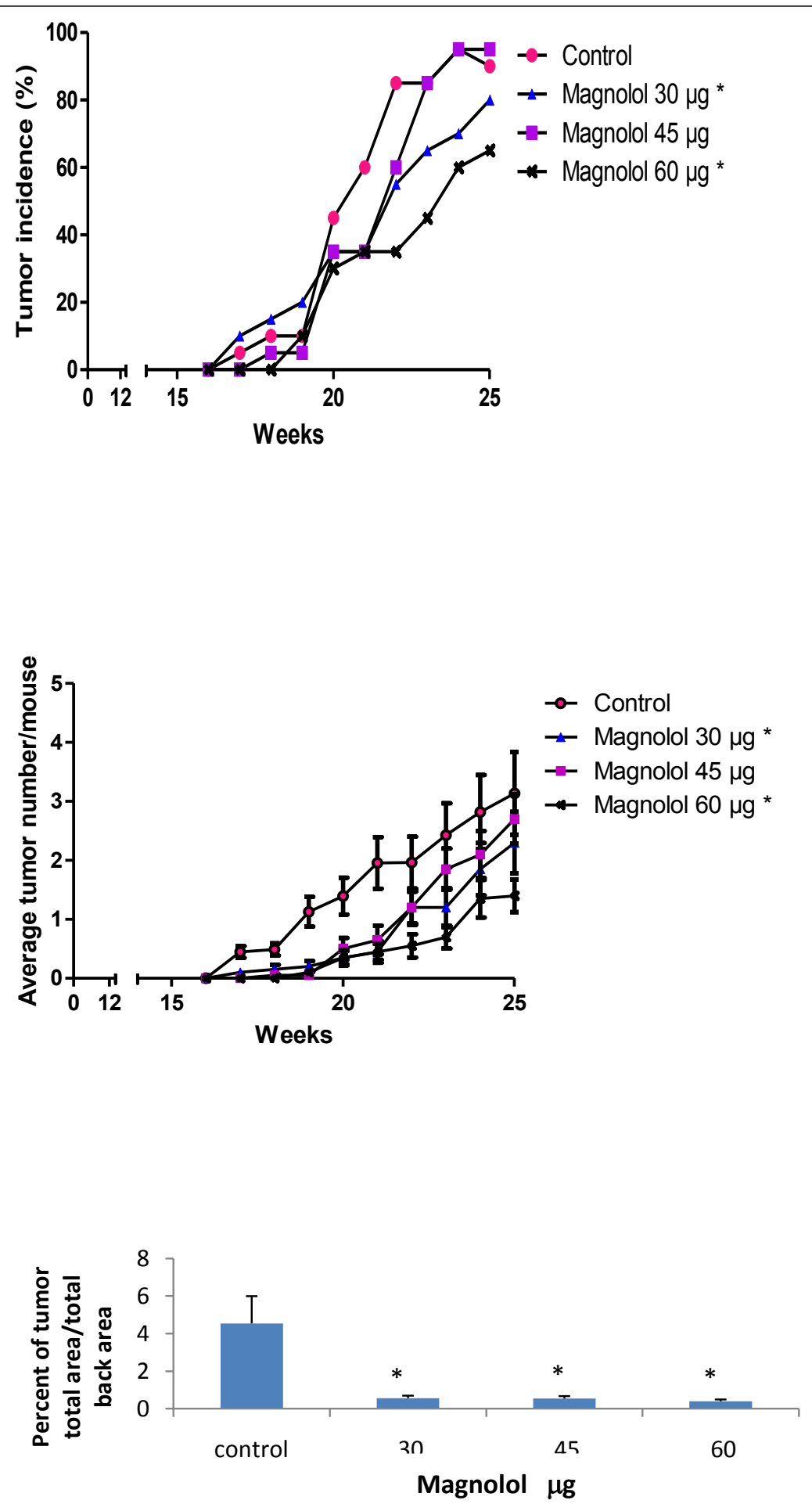

Figure 1 Effects of magnolol pretreatment on tumor incidence, tumor multiplicity and tumor area in UVB-induced skin carcinogenesis in SKH-1 mice. (A) Effects of topical magnolol pretreatment on tumor incidence. From the $20^{\text {th }}$ week to the end of the experiment magnolol $30 \mu \mathrm{g}$ and $60 \mu \mathrm{g}$ reduced significantly tumor incidence. Each point represents the percentage of animals bearing at least one tumor, values derived from 20 mice. *Significant difference $(p<0.05)$. (B) Effects of magnolol pretreatment on tumor multiplicity. Magnolol 30 and $60 \mu \mathrm{g}$ pretreatment significantly decreased tumor multiplicities from the $16^{\text {th }}$ to $25^{\text {th }}$ week of UVB induced carcinogenesis. Each point represents mean number of tumors per mouse \pm SE derived from 20 mice. *Significant difference $(p<0.05)$. (C) Effects of magnolol treatment on tumor area. Average ratio of total tumor area to total back area of the SKH-1 mice. Each bar represents mean ratio of tumor area per mouse \pm SE derived from 20 mice.* Significant difference $(p<0.05)$ 


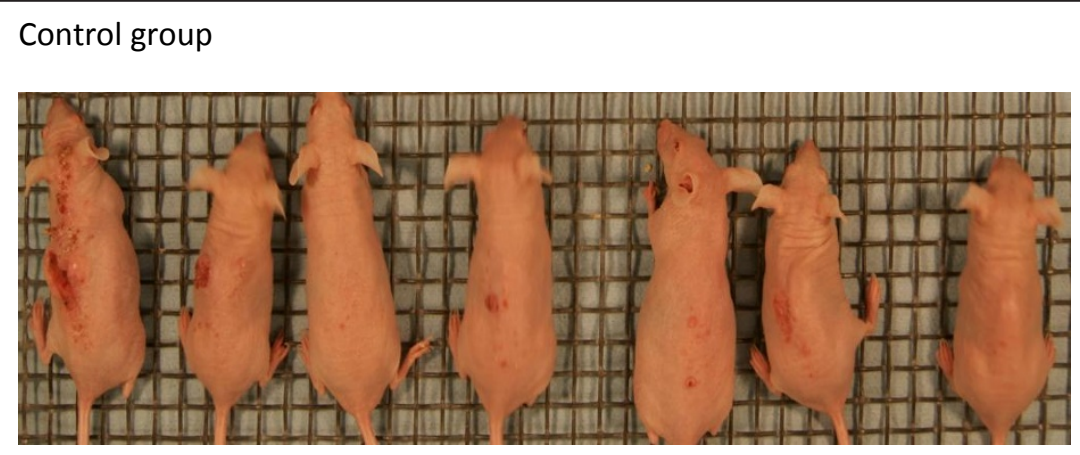

Magnolol $30 \mu \mathrm{g}$

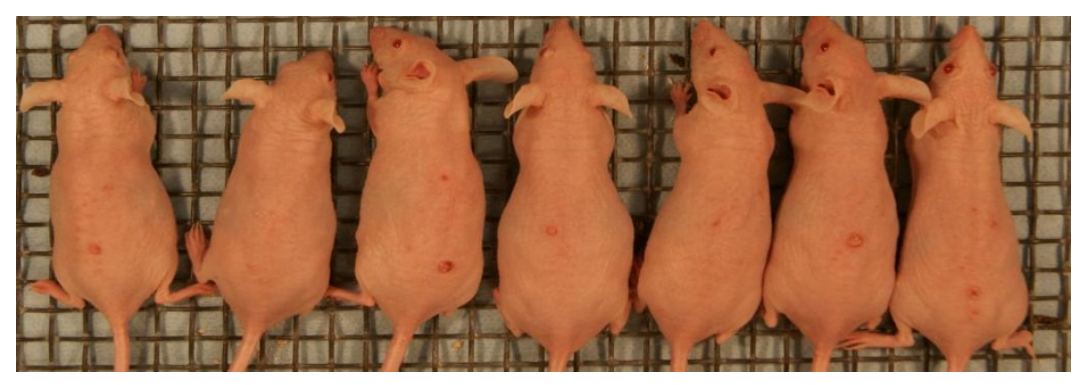

Magnolol $45 \mu \mathrm{g}$

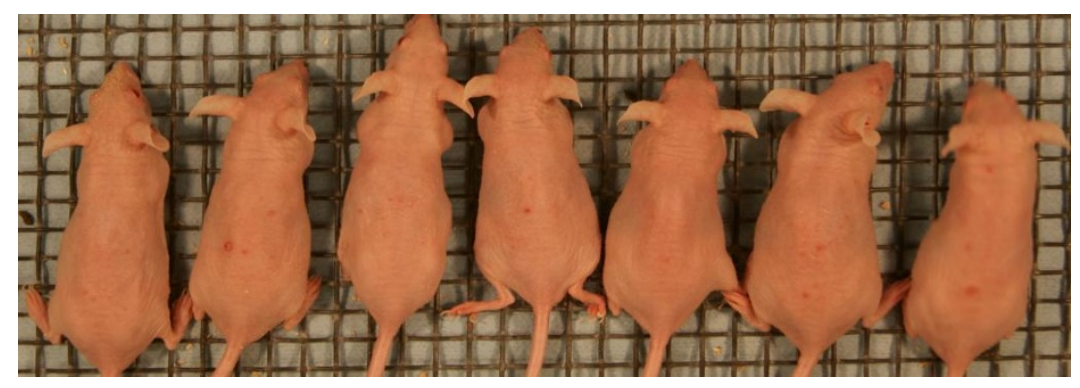

Magnolol $60 \mu \mathrm{g}$

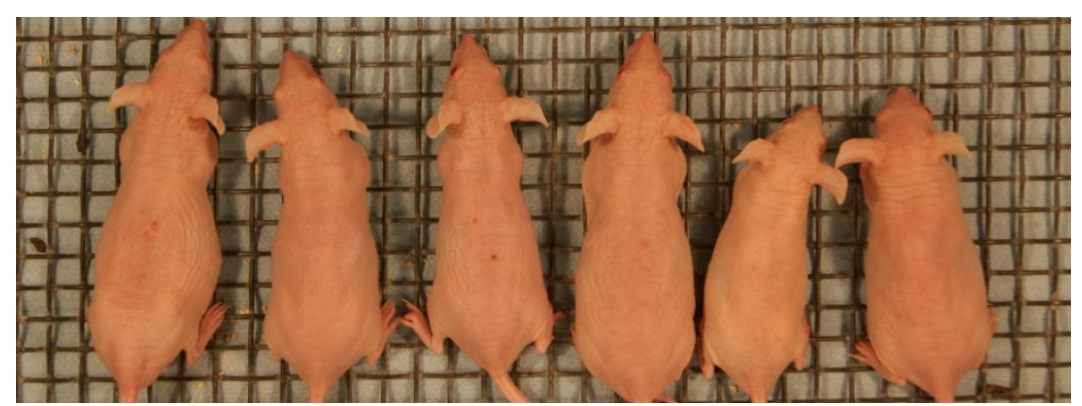

Figure 2 Effects of magnolol treatment on UVB induced skin tumors in SKH-1 mice. Mice were exposed five days a week to $30 \mathrm{~mJ} / \mathrm{cm}^{2}$ UVB one hour before different topical treatments. Control group $(n=20)$ was treated with $200 \mu$ I of acetone. Treatment groups ( $n=20$ each) received 30, 45 or $60 \mu \mathrm{g}$ of magnolol dissolved in $200 \mu \mathrm{I}$ of acetone. Pictures were taken at the end of the $25^{\text {th }}$ week. Animals were randomly chosen for the pictures. 


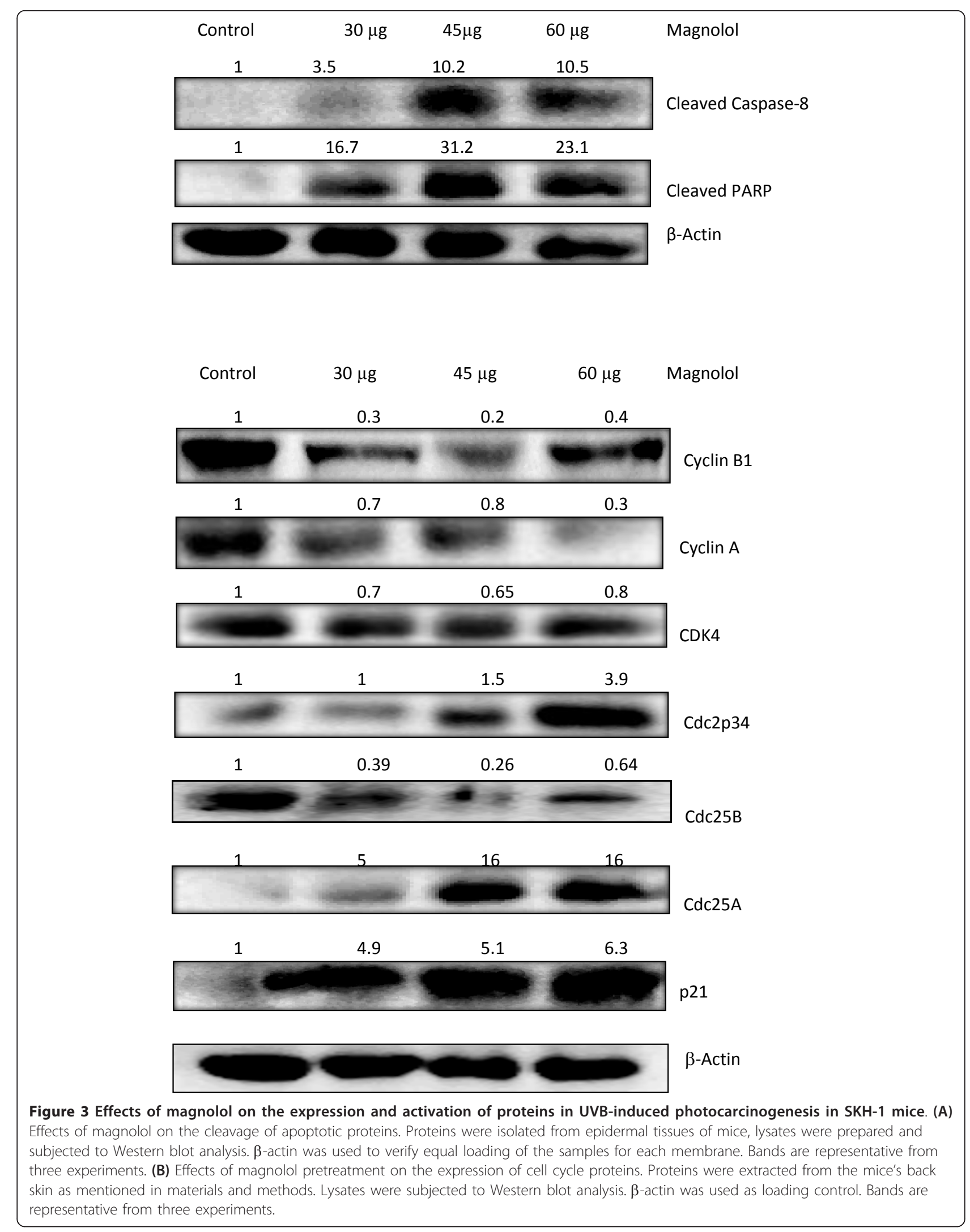


Magnolol treatment decreased cell viability in A431 cells As this is the first time the effects of magnolol on human epidermoid carcinoma A431 cells are investigated, MTT assay was conducted to determine the effects of magnolol on cell viability. A431 cells double in 24 hours [33,34]; therefore we studied the effects of magnolol treatment at 12, 24 and 48 hours. Magnolol treatment $(75-125 \mu \mathrm{M})$ showed a concentration and time dependent decrease in cell viability Figure 4A. Magnolol treatment did not show a significant effect at $12 \mathrm{~h}$, but at $24 \mathrm{~h}$ and $48 \mathrm{~h}$ treatment significantly decreased cell viability. The effects of magnolol at $48 \mathrm{~h}$ may not be due to cell death but due to proliferation inhibition. As shown in Figure 4A, cell viability of

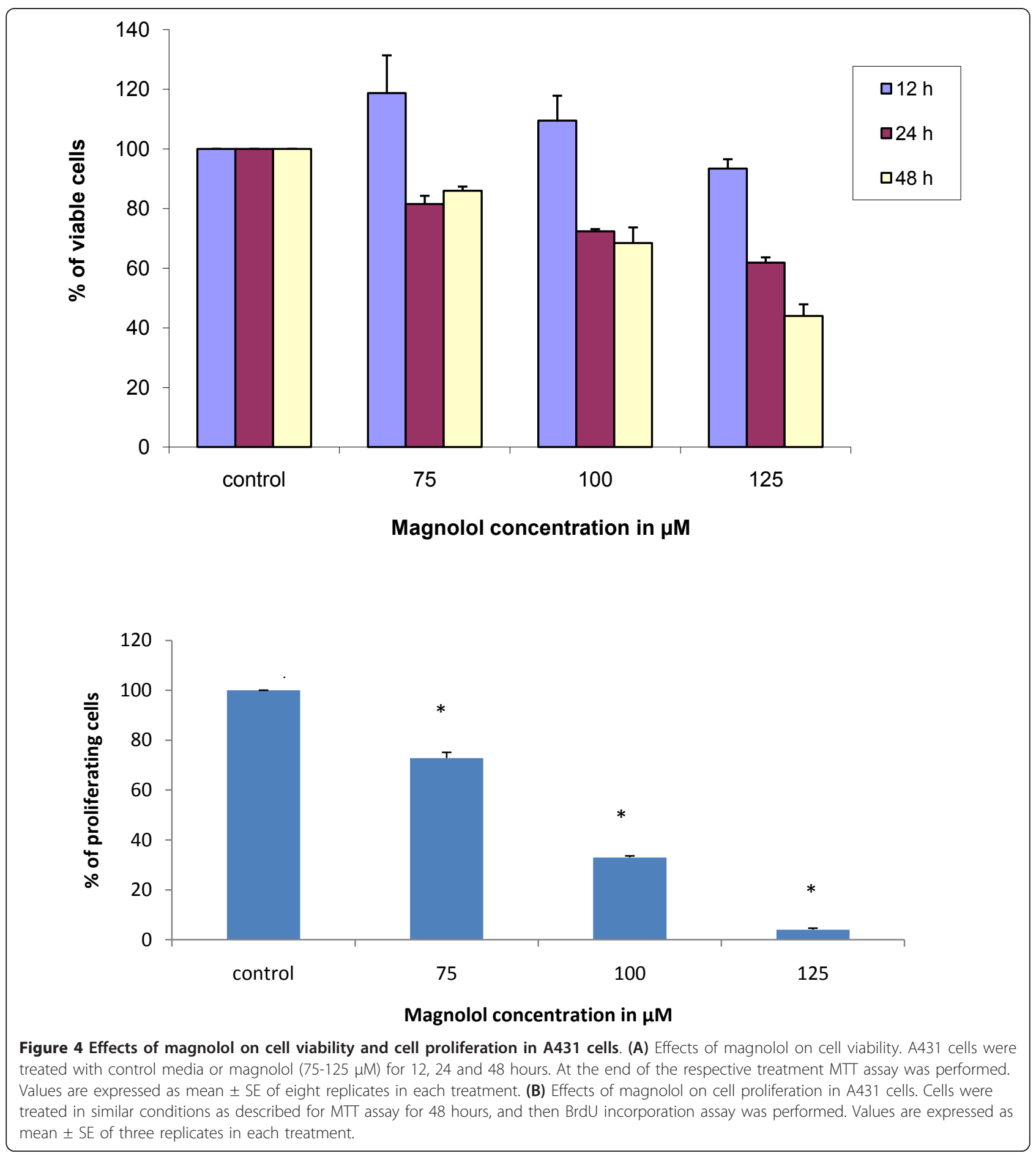


magnolol treated cells compared to controls ranged from $100-98 \%$ at $12 \mathrm{~h}, 80-70 \%$ at $24 \mathrm{~h}$ and $80-50 \%$ at $48 \mathrm{~h}$.

\section{Magnolol inhibited cell proliferation in A431cells}

We investigated the effects of magnolol on cell proliferation in A431cells by BrdU incorporation assay. Magnolol $(75-125 \mu \mathrm{M})$ at 48 hours treatment resulted in a $30-96 \%$ decrease in cell proliferation as compared to control. Figure 4B.

\section{Magnolol induces apoptosis in A431 cells}

To investigate whether cell death caused by magnolol is an apoptotic response, cells were treated with magnolol $(100,150 \mu \mathrm{M})$ for $48 \mathrm{~h}$, followed by annexin-V/PI staining using a Vibrant Apoptosis kit. The stained cells were analyzed through flow cytometry. As shown in Figure 5, early apoptotic cells are represented in the lower right quadrant and late apoptotic cells in the upper right quadrant. The results showed that magnolol treatments $(100$ and $150 \mu \mathrm{M})$ resulted in $14.2 \%$ and $31.4 \%$ of apoptosis respectively compared with DMEM $0.4 \%$ DMSO treated control showing $8.8 \%$ of apoptotic cells. These results suggest magnolol treatment induced a significant degree of apoptosis $(p<0.05)$ in a concentration dependent manner. This data supports the results from our animal experiments.

\section{Magnolol induces DNA fragmentation in A431 cells}

TUNEL assay was performed in order to investigate the effects of magnolol on DNA fragmentation, which is hallmark of late apoptosis that commits cells to die. As shown in Figure 6A, M1 gate is used to indicate DNA fragmented cells. Compared with the DMEM 0.4\% DMSO treated control showing $0.8 \%$ of DNA fragmentation, magnolol treated A431 cells at 100 and $150 \mu \mathrm{M}$ resulted in $1.17 \%$ and $21 \%$ of DNA fragmentation after 48 hours treatment. These results suggest that $100 \mu \mathrm{M}$ did not induce DNA fragmentation whereas $150 \mu \mathrm{M}$ concentration significantly increased DNA fragmentation. Figure 6A.

\section{Control}
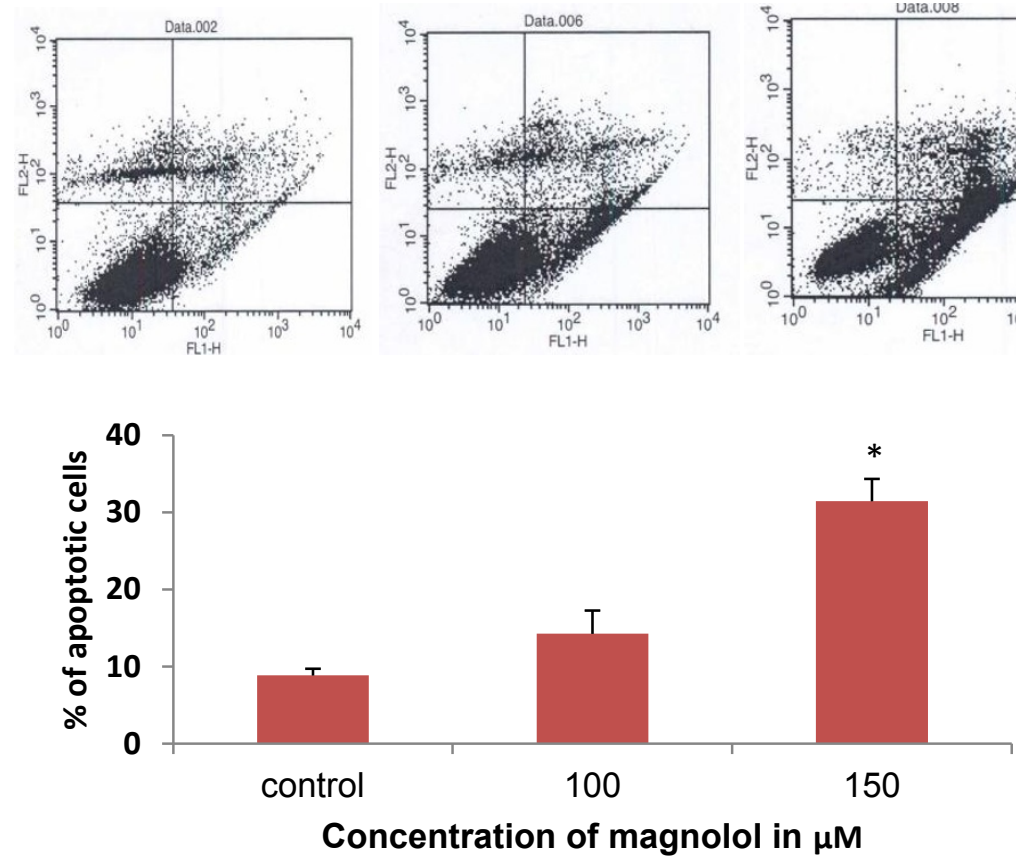

Figure 5 Effects of magnolol on apoptosis in A431 cells as assessed by annexin-V/PI staining. Cells were treated with magnolol (0-150 $\mu \mathrm{M})$ for $48 \mathrm{~h}$, at the end of the treatment adherent and non-adherent cells were collected and treated with annexin- $\mathrm{V}$ labeled with a fluorophore, which can identify apoptotic cells by binding to phosphatidylserine exposed on apoptotic cells; and with propidium iodide that stained dead cells. Dot plot of annexin-V (FL1-H)/PI (FL2-H) staining of A431 cells by flow cytometry. The lower right quadrant shows early apoptotic cells that are labeled with annexin- $V$, having green fluorescence. The upper right quadrant stained by annexin- $V$ and $P I$ indicates late apoptotic cells. The lower left quadrant contains viable cells which exclude PI and are negative for annexin-V staining, and the upper left quadrant are necrotic cells stained by PI only. The bar graph describes the percentages of apoptotic cells after each treatment. In each case data represent mean \pm SE of three observations. ${ }^{*} p<0.05$ indicates statistical significant difference in magnolol treated groups compared with the control. 


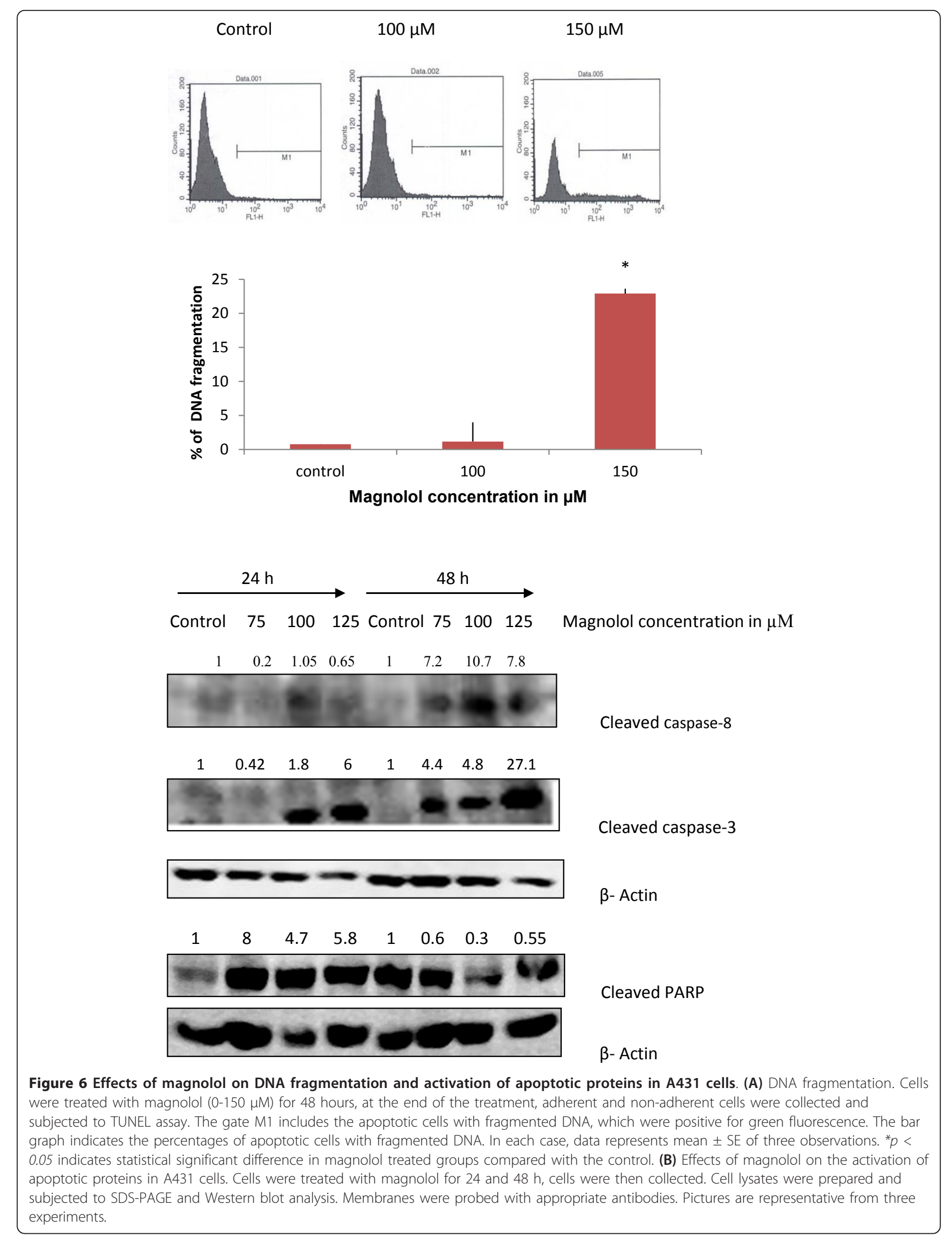




\section{Magnolol induces cleavage of caspases and PARP during apoptosis in A431 cells}

Western blot analysis for caspases was used to further investigate magnolol induced apoptosis in A431 cells. The results showed that magnolol treatment increased the expression of cleaved caspase-8, and cleaved caspase-3 in a concentration dependent manner. We observed increased cleavage of PARP only at $24 \mathrm{~h}$, membranes were checked for equal protein loading using $\beta$-actin as control. Figure 6B.

\section{Magnolol induces G2/M cell cycle arrest}

To determine the mechanism involved in antiproliferative activity, the effects of magnolol on cell cycle progression were studied in A431 cells. The effects of magnolol on the cell cycle were determined following treatment with 75,100 and $125 \mu \mathrm{M}$ of magnolol for 12 h, $24 \mathrm{~h}$, and $48 \mathrm{~h}$. As shown in Figure 7A and 7B, magnolol treatment resulted in a significantly increased number of cells in G2/M phase following $12 \mathrm{~h}$ at 100 $\mu \mathrm{M}(33.45 \%)$ and $125 \mu \mathrm{M}(45.79 \%)$ compared with the control (22\%). The concentration dependent effect of magnolol on G2/M arrest is at the expense of the G0/ G1 phase (Figure $7 \mathrm{~B}$ ). These results are in agreement with the data from animal experiments (Figure $3 \mathrm{~B}$ ).

\section{Magnolol decreases expressions of G2/M regulatory proteins Cdks and cyclins and increased Cip1/p21 in A431 cells}

As cell cycle progression is dependent on various cyclins and cyclin-dependent kinases (CDK's), we focused our interest on investigating the expression of A431cell cycle proteins after magnolol treatment. Magnolol treatment resulted in strong inhibition in the expression of cyclin B1 (a protein involved in M phase) and cyclin A (a protein involved in both $\mathrm{S}$ and $\mathrm{G} 2$ phases) in a concentration and time dependent manner with almost disappearance of bands with higher concentrations. Magnolol treatment also decreased the expression of CDK2 and CDK4 in a concentration dependent manner at $24 \mathrm{~h}$ and $48 \mathrm{~h}$. Reduction of CDK4 is more pronounced than CDK2 (Figure 8)

To further elucidate the mechanisms involved in the G2/M cell cycle arrest after magnolol treatment, we investigated various proteins involved in the $\mathrm{G} 2 / \mathrm{M}$ phase. Magnolol treatment to A431 cells resulted in a decreased expression of Cdc2p34, Cdc25A, Cdc25C and pCdc25C (Ser216). All these results taken together suggest that magnolol induces $\mathrm{G} 2 / \mathrm{M}$ cell cycle arrest through the modulation of $\mathrm{G} 2 / \mathrm{M}$ regulatory proteins (Figure 8).

We next assessed the effects of magnolol on the expression of Cip1/p21, a cyclin dependent kinase inhibitor which is known to regulate the cells at the G1-S check point [35]. Magnolol treatment to A431 cells resulted in a significant increase in the expression of p21 in a concentration dependent manner compared with control cells. Collectively all these results suggest that increase in CDK inhibitory protein $\mathrm{p} 21$ by magnolol may have a role in cell cycle arrest in G2/M phase of A431 cells (Figure 8).

\section{Magnolol inhibits STAT3 phosphorylation in A431 cells}

In order to investigate the molecular mechanism of magnolol in A431 cells, we first assessed the effects of magnolol on STAT3 phosphorylation. The effects of magnolol on STAT3 phosphorylation are shown in Figure 9. Compared with control treated cells, magnolol treated cells showed inhibition of STAT3 phosphorylation at Tyr705 at 24 and $48 \mathrm{~h}$, as well as inhibition of phosphorylation of STAT3 at Ser 727 for 100 and 125 $\mu \mathrm{M}$ at $48 \mathrm{~h}$. Magnolol treatment resulted in a time and concentration dependent decrease in p-STAT3 Tyr705. Downstream targets of STAT3 include PCNA and cyclin D1 [24]. We found that magnolol treatment decreased the expression of these proteins (Figure 9).

\section{Effects of magnolol on B-Raf, p-MEK, ERK and AKT in A431 cells}

We next assessed the effects of magnolol on proliferation markers. MAPK signaling pathway play an important role in cell proliferation, and cell growth arrest [36]. We investigated the effects of magnolol on B-Raf, p-MEK, p-ERK in A431 cells at 24 and 48 h. Results showed that magnolol treatment decreased the expression levels of B-Raf and phosphorylation of MEK in a concentration dependent manner (Figure 10). Our results showed that ERK activation is increased for 125 $\mu \mathrm{M}$ at 24 and $48 \mathrm{~h}$ suggesting that magnolol induces cell growth inhibition by activating ERK. In addition to this, we found that magnolol treatment decreased the phosphorylation of AKT.

\section{Discussion}

Magnolol, a hydroxylated biphenolic compound isolated from Magnolia officinalis, most commonly used in traditional Chinese medicine has been investigated for its effects on skin carcinogenesis. In this study, we determined the effect of magnolol in UVB-induced skin cancer in SKH-1 mice and on a human epidermoid skin cancer cell line in vitro. Neolignans from Magnolia officinalis delayed papilloma formation in skin tumor promotion by TPA [21,37]. We investigated the effects of magnolol in a UVB-induced skin carcinogenesis model with a UVB dose of $30 \mathrm{~mJ} / \mathrm{cm}^{2} /$ day which is more translational and relevant to human skin cancer as compared to previous studies that used higher doses of UV radiation [5,15]. Magnolol $30 \mu \mathrm{g}$ and $60 \mu \mathrm{g}$ in $200 \mu \mathrm{l}$ of 


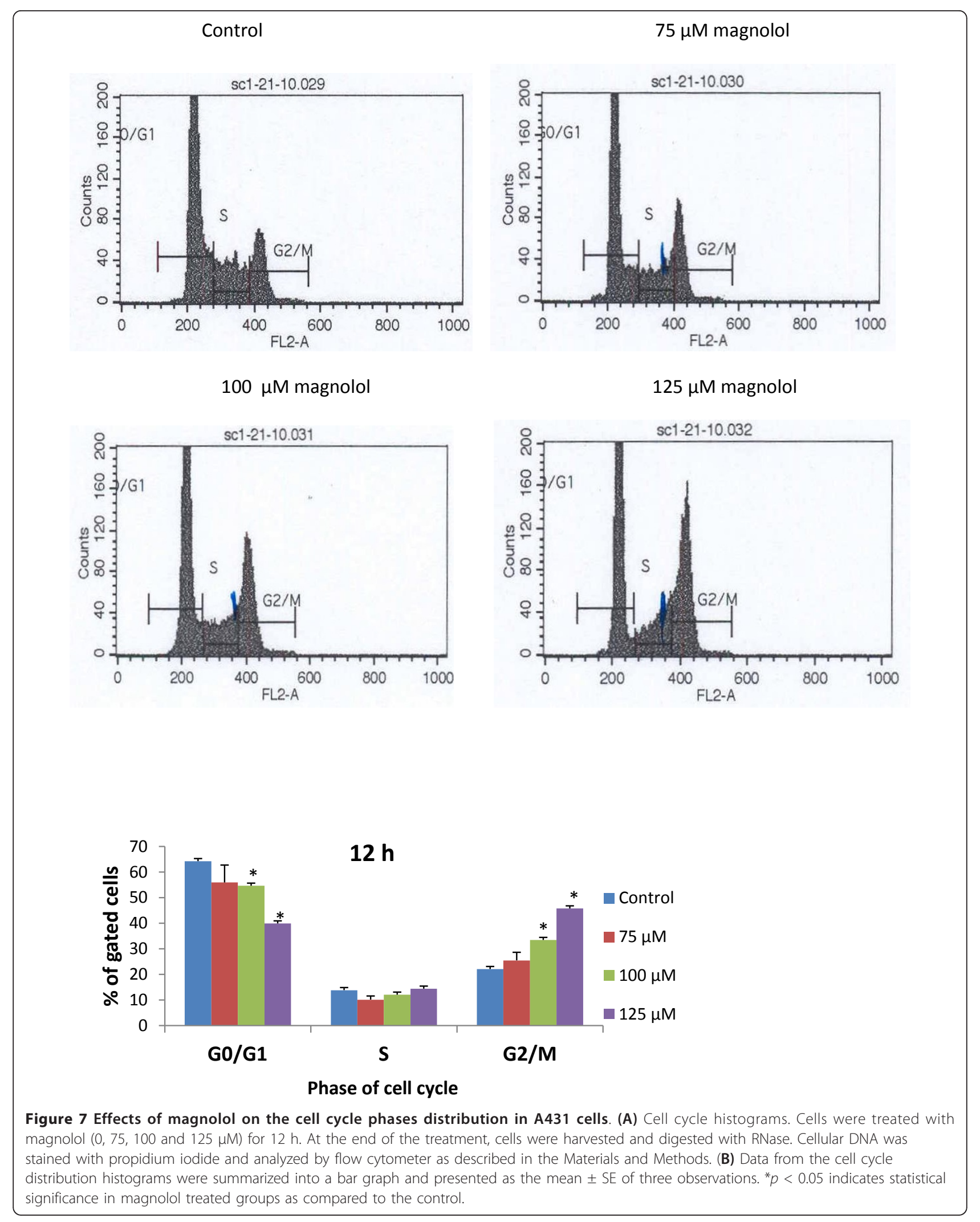




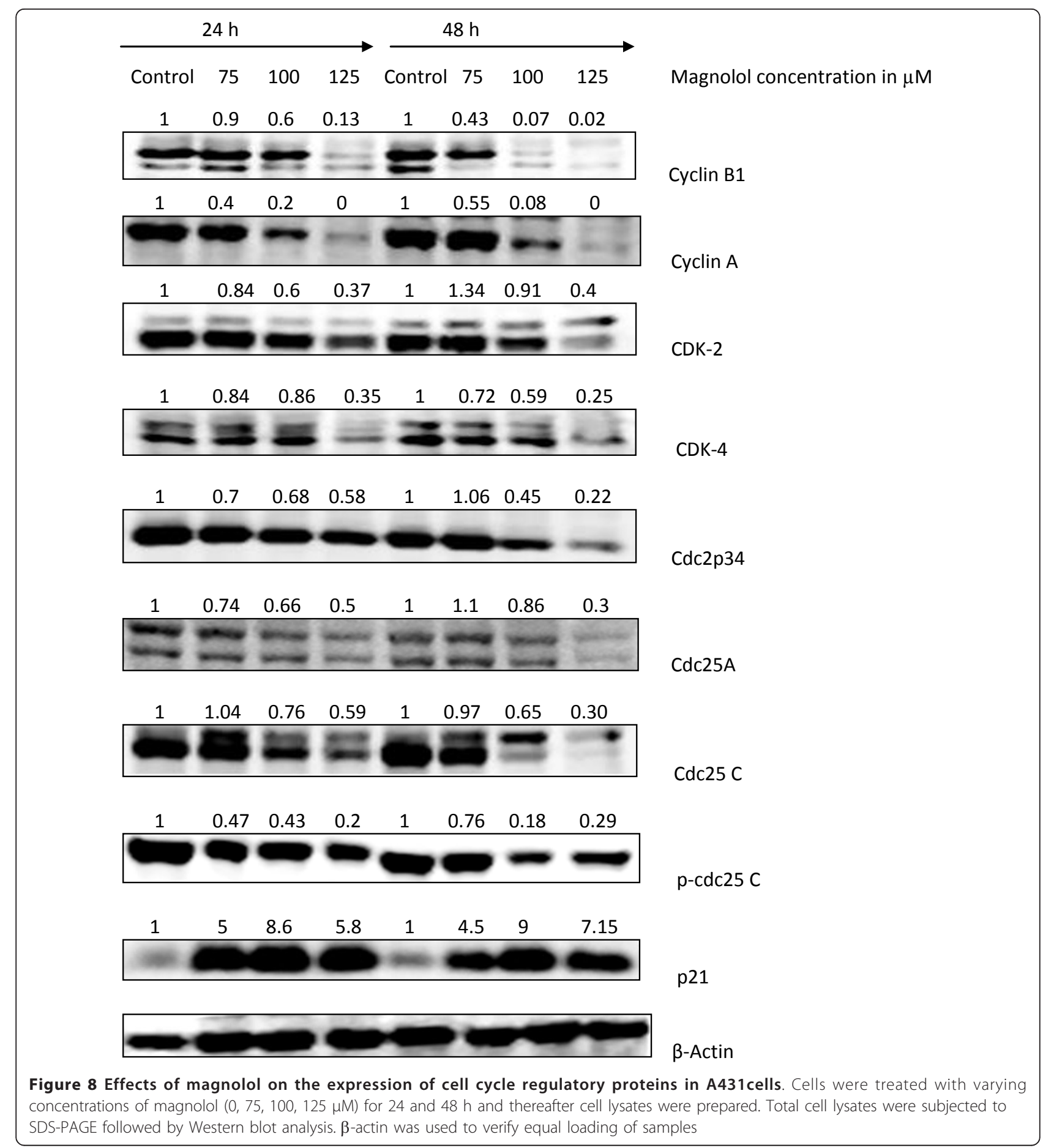

acetone showed a protective effect in a dose dependent manner when applied topically. In this study interestingly, $45 \mu \mathrm{g}$ magnolol did not have any effect on tumor incidence and lower effects than the $30 \mu \mathrm{g}$ application in tumor multiplicity. Magnolol may have biphasic effects on various target proteins not investigated in this study, thus the middle dose is less effective than the lower dose. Further studies with an increased range of magnolol doses are needed to fully understand this biphasic effect. We used very low doses (in micrograms) of magnolol compared to other chemopreventive agents which use milligrams per applications $[5,13]$ thus indicating the higher potency of magnolol over other agents. The results demonstrated that magnolol delayed the 


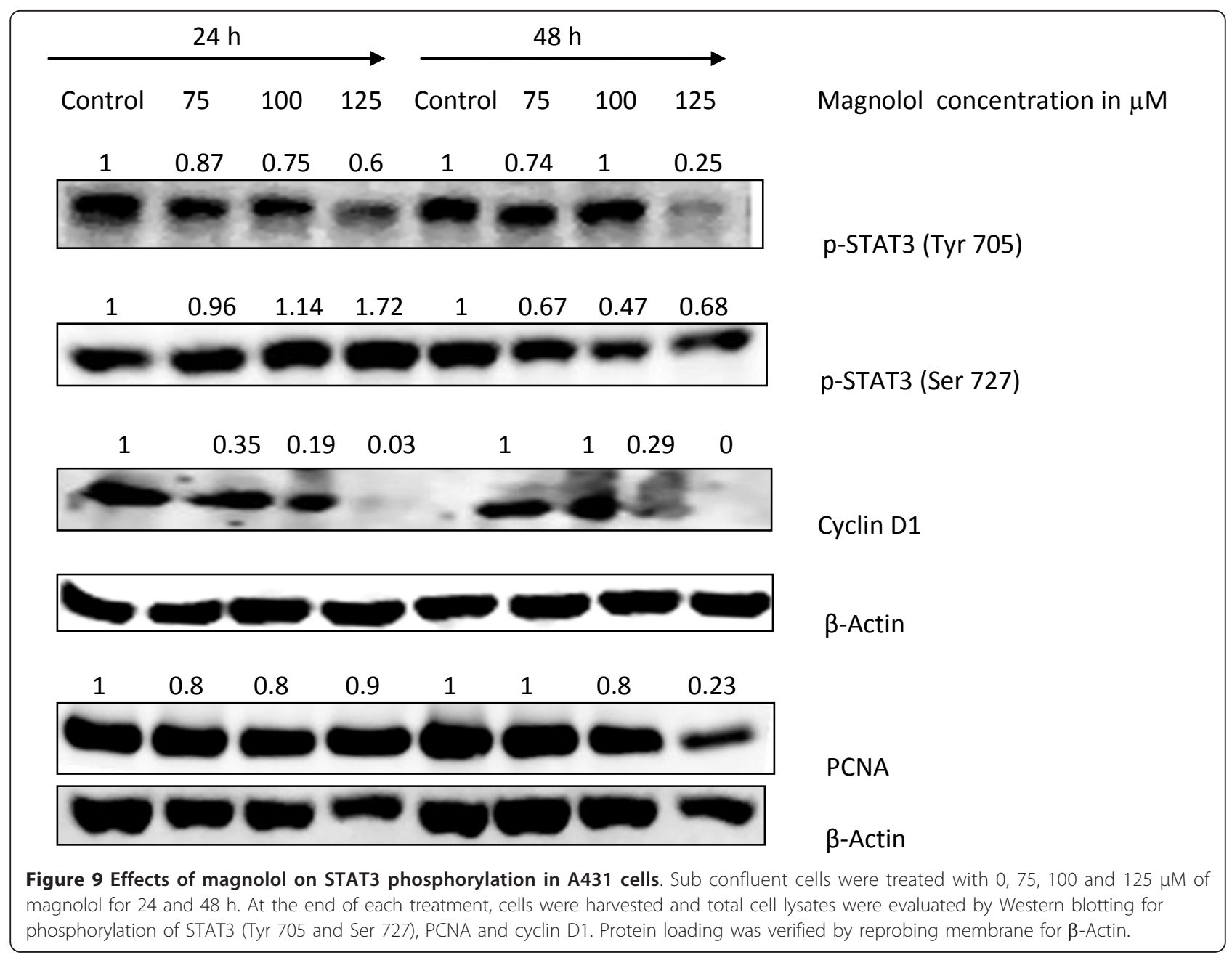

onset of tumorigenesis when compared to the control. Tumor multiplicity was reduced by $27-55 \%$ for $30 \mu \mathrm{g}$ and $60 \mu \mathrm{g}$ of magnolol respectively compared to the control.

Mechanistic studies showed that magnolol induced apoptosis through extrinsic pathway and affected tumor development by causing cell cycle arrest at G2/M phase in our animal models.

To gain insight and have understanding of signaling mechanisms involved in the magnolol anticarcinogenic effect, we used human epidermoid A431 cells as an in vitro model. Magnolol inhibits cell viability and proliferation which together contributed to overall inhibition of cell growth in A431 cells at concentrations 75-125 $\mu \mathrm{M}$ for $12-48 \mathrm{~h}$. Cancer development involves deregulation in cell cycle progression. Control of the cell cycle plays an important role in controlling tumor growth $[22,38]$. As such, effects of magnolol on the cell cycle and its related proteins were investigated in A431 cells. The results obtained demonstrate that magnolol induced G2/M cell cycle arrest, is one mechanism of inhibition of cell viability and proliferation. As cyclins/cyclin dependent kinases tightly regulate the cell cycle progression $[39,40]$, the effects of magnolol on cell cycle proteins were investigated. Our findings revealed that treatment of cells with magnolol resulted in a significant decrease in cyclin A, cyclin B1, CDK2, CDK4, Cdc2 and increase in $\mathrm{Cip} 1 / \mathrm{p} 21$ expression at all concentrations compared to control. Our studies on honokiol [17], an isomer of magnolol have indicated similar anticarcinogenic effects as magnolol. However, honokiol caused cell cycle arrest at G0/G1 phase in A431 cells [41] unlike magnolol which caused cell cycle arrest at G2/M phase.

Anticarcinogenic effects are modulated by two major events: inhibition of cell proliferation and induction of apoptosis [25,42]. Accordingly, the effects of magnolol on induction of apoptosis in A431 cells were investigated. During apoptosis, cells undergo changes such as loss of phospholipids asymmetry of the plasma membrane, cell shrinkage, proteases activation and finally DNA fragmentation [43]. Our flow cytometry data demonstrated that magnolol significantly induced 


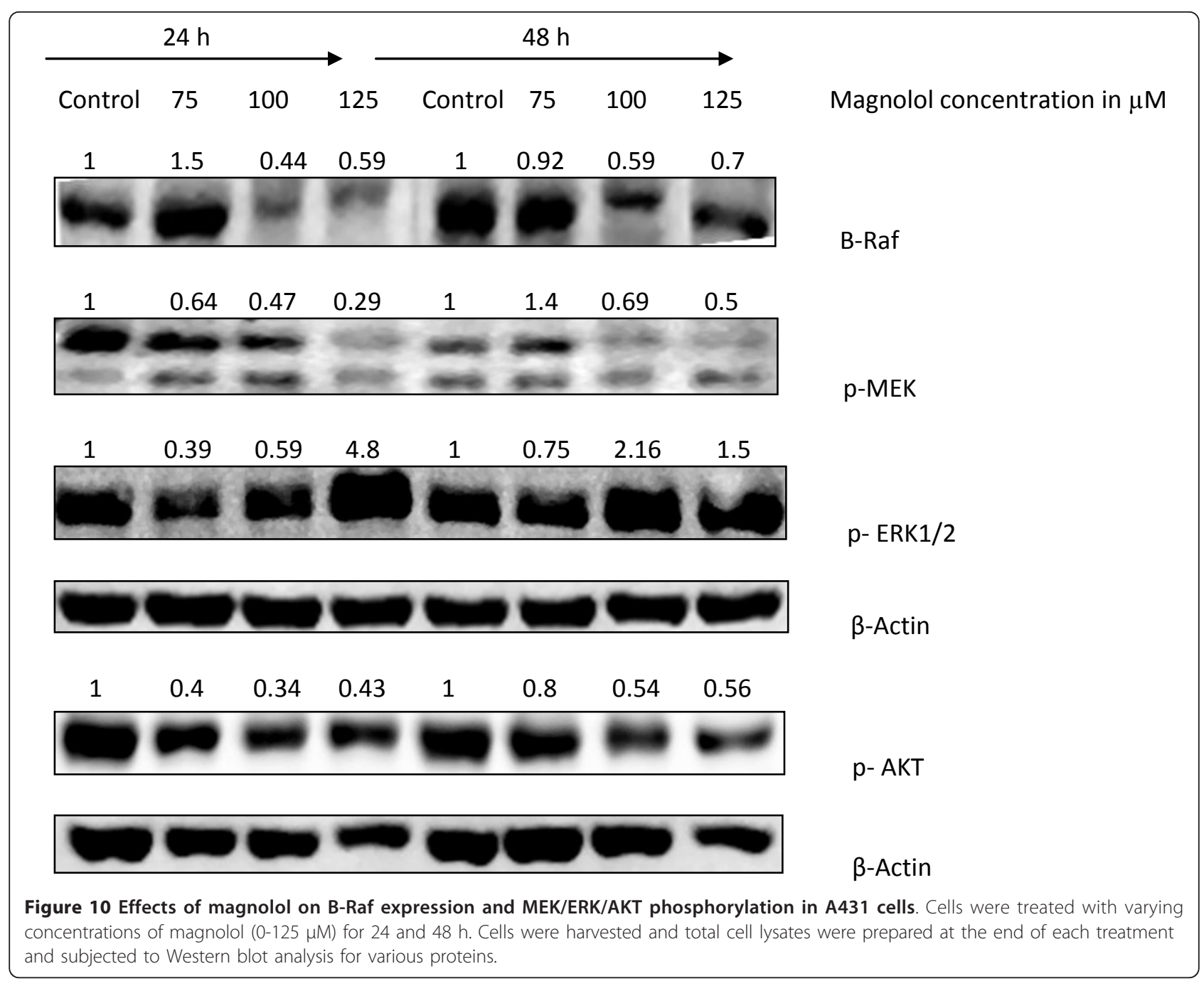

apoptosis in A431 cells as assessed by annexin-V/PI staining which detects apoptotic cells by their loss of phospholipids plasma membrane asymmetry. Then, later we examined DNA fragmentation in apoptotic cell by using TUNEL assay. Magnolol 48h treatment induced DNA fragmentation in A431 cells at higher concentrations $(150 \mu \mathrm{M})$.

There are two reported pathways for the induction of apoptosis. In the extrinsic or death receptor pathway of apoptosis, activation of death receptors by ligands leads to activation of caspase- 8 . This activated caspase- 8 can activate caspase-3, an executioner caspase. Activated caspase3 can cleave PARP and thereby results in apoptosis $[44,45]$. Consistent with the above reports, magnolol treatment to A431 cells activated caspase- 8 and caspase- 3 in a concentration dependent manner that led to PARP cleavage. These observations suggest that magnolol induced apoptosis through extrinsic pathway and are consistent with the results obtained from animal experiments.
The STAT pathway regulates the transcription of a wide variety of genes involved in proliferation, development, and tumorigenesis $[46,47]$. Among different STAT family members, STAT3 is implicated in tumorigenesis [47] and it plays an important role in skin cancer development [48]. STATs are activated either by serine or tyrosine phosphorylation by JAK kinases, then they undergo dimerization followed by nuclear translocation and regulation of the expression of target genes [49]. Our results showed that treatment of A431 cells with magnolol inhibited the phosphorylation of STAT3 at tyrosine residues. Downstream targets of p-STAT3 include cyclin D1, our results showed that magnolol decreased cyclin D1 expression, and this may lead to cell cycle arrest [50]. In the present study, our in vitro data has shown that magnolol treatment increased the phosphorylation of ERK protein in A431 cells, suggesting activation of ERK and upregulation of p21 by magnolol as a mechanism for cell cycle arrest [51]. 
However, further studies are needed to study the effects of magnolol on the phosphorylation of these proteins at very early stages instead of at $24 \mathrm{~h}$ and $48 \mathrm{~h}$.

Magnolol inhibited cell proliferation through regulation of Cip1/p21 in human glioblastoma cells [52], induced apoptosis via inhibition of EGFR, PI3K/AKT signaling pathways in human prostate cancer cells [36] and inhibited MMP-9 expression through the transcription factor NF-kB in TNF- $\alpha$ - induced human urinary bladder cancer cells [53]. Magnolol induces apoptosis via activation of both mitochondrial and death receptor pathways in A375-S2 malignant melanoma cells [54]. Recent studies by Tanaka et al. [55], have shown the preventive effects of magnolol on UV-induced photoaging by inhibiting the expression of NF-kB. A recent study by Kuo et al. [35] showed that magnolol downregulated TPA induced iNOS and COX-2 gene expression in mouse skin suggesting that magnolol could be novel agent preventing inflammation associated tumorigenesis.

Our studies for the first time provided the evidence that magnolol pretreatment at very low doses (micrograms per applications compared to most other agents which are used in milligrams per application) prevents UVB-induced skin cancer development in SKH-1 mice by both inducing apoptosis and decreasing cell proliferation through modulation of various signaling pathways. The sunscreen effects of magnolol have not been investigated in this study which may contribute to anticarcinogenic effects. Future studies involving various inhibitors, antisense oligonucleotides and dominant negative mutants or siRNA are needed to map the pathways to conclude the signaling involved in the anticancer effects of magnolol. Magnolol has a great potential to be a safe and potent chemopreventive agent against skin cancer development in human.

\section{Conclusions}

Our studies for the first time provided the evidence that magnolol pretreatment at very low doses (micrograms per application compared to most other agents which are used in milligrams per application) prevents UVB-induced skin cancer development in SKH-1 mice both by inducing apoptosis and decreasing cell proliferation through modulation of various signaling pathways. Magnolol has a great potential to be a safe and potent chemopreventive agent against skin cancer development in human.

\section{Acknowledgements}

Authors gratefully acknowledge Dr. G. Chandrasekher for providing p-ERK1/2, p-AKT antibodies and helpful suggestions. This study was supported by the Department of Pharmaceutical Sciences Graduate Program and Translational Cancer Research Center funded by the State of South Dakota.

\section{Author details}

'Department of Pharmaceutical Sciences, South Dakota State University, Brookings, SD 57007, USA. ${ }^{2}$ ACEA Bio Ltd., Hangzhou, P.R. China. ${ }^{3}$ Department of Biology and Microbiology, South Dakota State University, Brookings, SD 57007, USA. ${ }^{4}$ Department of Veterinary and Biomedical Sciences, South Dakota State University, Brookings, SD 57007, USA.

\section{Authors' contributions}

CC has performed UVB induced skin cancer development in SKH-1mice, in vitro assays and Western blots for various proteins for A431cells and wrote the manuscript; RG performed Western blots for cell cycle and apoptotic proteins from tissue samples. XZ helped with Western blots. RSK and AY helped with flow cytometric analysis; DZ performed the histopathological examination of samples; $\mathrm{MH}$ helped with image pro analysis; HF identified the magnolol for the studies; and CD overall conceived and executed the idea, and prepared the final draft of manuscript. All authors read and approved the final manuscript.

\section{Competing interests}

The authors declare that they have no competing interests.

Received: 7 March 2011 Accepted: 20 October 2011

Published: 20 October 2011

\section{References}

1. Rogers HW, Weinstock MA, Harris AR, Hinckley MR, Feldman SR, Fleischer AB, Coldiron BM: Incidence estimate of nonmelanoma skin cancer in the United States, 2006. Arch Dermatol 2010, 146:283-287.

2. Siegel R, Ward E, Brawley O, Jemal A: Cancer Statistics, 2011. CA Cancer J Clin 2011, 61:212-236.

3. Kremer KH: Sunlight and skin cancer: Another link revealed. Proc Natl Acad Sci USA 1997, 95:11-14.

4. Lu YP, Lou YR, Yen P, Mitchell D, Huang MT, Conney AH: Time course for early adaptive responses to ultraviolet B light in the epidermis of SKH-1 mice. Cancer Res 1999, 4591-4602.

5. Katiyar SK, Korman NJ, Mukhtar H, Agarwal R: Protective effects of silymarin against photocarcinogenesis in a mouse skin model. J Natl Cancer Inst 1997, 89:556-566.

6. Koh HK: Preventive strategies and research for ultraviolet-associated cancer. Environ Health Perspect 1995, 103:255-257.

7. Rigel DS, Friedman R, Kopf AW: Lifetime risk for development of skin cancer in the US population: Current estimate is now 1 in 5. J Am Acad Dermatol 1996, 35:1012-1013.

8. De Gruijil FR: Photocarcinogenesis: UVA vs UVB radiation. Skin Pharmacol Appl Skin Physiol 2002, 15:316-320.

9. Tyrell RM: Activation of mammalian gene expression by the UV component of sunlight-from models to reality. Bioessays 1996, 18:139-148.

10. Pinnell SR: Cutaneous photodamage, oxidative stress and topical antioxidant protection. J Am Acad Dermatol 2003, 48:1-19.

11. Wolf $P$, Donawho CK, Kripke ML: Effects of sunscreens on UV radiationinduced enhancement of melanoma growth in mice. $J$ Natl cancer inst 1994, 86:99-105.

12. Dwivedi C, Maydew ER, Hora J, Ramaeker D, Guan X: Chemopreventive effects of various concentrations of alpha-santalol on skin cancer development in CD-1 mice. Eur J Cancer Prev 2005, 14:473-476.

13. Gu M, Singh RP, Dhanalakshmi S, Agarwal C, Agarwal R: Silibinin inhibits inflammatory and angiogenic attributes in photocarcinogenesis in SKH-1 hairless mice. Cancer Res 2007, 67:3483-3491.

14. Surh YJ: Cancer chemoprevention with dietary phytochemicals. Nat Rev Cancer 2003, 3:768-780

15. Won YK, Ong C, Shi X, Shen HM: Chemopreventive activity of parthenolide against UVB-induced skin cancer and its mechanisms. Carcinogenesis 2004, 25:1449-1458.

16. Einspahr JG, Bowden GT, Alberts DS: Skin cancer chemoprevention: strategies to save our skin. Recent Results Cancer Res 2003, 163:151-164, discussion 264-6.

17. Chilampalli S, Zhang X, Fahmy H, Kaushik RS, Zeman D, Hildreth M, Dwivedi C: Chemopreventive effects of honokiol on UVB-induced skin cancer development. Anticancer Research 2010, 30:777-784. 
18. Fugita S, Taira J: Biphenyl compounds are hydroxyl radiacl scavengers: their effective inhibition for UV-induced mutation in salmonella tyhimurium TA 102. Free Radic Biol Med 1994, 17:273-277.

19. Wang JP, HSU MF, Raung SL, Chen CC, Kuo JS, Teng CM: Antiinflammatory and analgesic effects of magnolol. Naunyn Schmiedebergs Arch Pharmacol 1992, 346:707-712.

20. Maruyuma $Y$, Kuribara H, Morita M, Yuzurihara M, Weintraub ST: Identification of magnolol and honokiol as anxiolytic agents in extracts of saiboku-to, an oriental herbal medicine. J Na Prod 1998, 61:135-138.

21. Konoshima T, Kozuka M, Tokuda H, Nishino H, Iwashima A, Haruna M, Ito K, Tanabe M: Studies on inhibitors of skin tumor promotion, IX. Neolignans from Magnolia officinalis. J Nat Prod 1991, 54:816-822.

22. Meeran SM, Katiyar SK: Cell cycle control as a basis for cancer chemoprevention through dietary agents. Front Biosci 2008, 13:2191-2202.

23. Cowan KJ, Storey KB: Mitogen activated protein kinases: new signaling pathways functioning in cellular responses to environmental stress and inflammation. J Exp Biol 2003, 206:1107-1115.

24. Hua Y, Richard J: The STATs of cancer- new molecular targets of age. Nat Rev Cancer 2004, 4:97-105.

25. Bachelor MA, Bowden GT: UVA mediated activation of signaling pathways involved in skin tumor promotion and progression. Semin Cancer Biol 2004, 14:131-138.

26. Han M, Golden A, Han Y, Sternberg PC: C. elegans lin-45 raf gene participates in let-60 ras-stimulated vulval differentiation. Nature 1993, 363:133-139.

27. Nishida $Y$, Hata M, Ayaki T: Proliferation of both somatic and germ cells is affected in the Drosophilla mutants of raf protoncogene. EMBO J 1988, 7:775-781.

28. Lu YP, Lou YR, Xie JG, Peng QY, Liao JYCS, Huang MT, Conney AH: Topical applications of caffeine or (-)-epigallocatechin gallate (EGCG) inhibits carcinogenesis and selectively increase apoptosis in UV B-induced skin tumors in mice. Proc Natl Acad Sci USA 2002, 99:12455-12460.

29. Zhang $X$, Bommareddy A, Chen W, Hildreth MB, Kaushik R, Zeman D, Khalifa S, Fahmy H, Dwivedi C: Chemopreventive effects of sarcophinediol on ultraviolet B induced skin tumor development in SKH-1 hairless mice. Marine Drugs 2009, 7:153-165.

30. Zhang X, Bommareddy A, Chen W, Khalifa S, Kaushik RS, Fahmy H, Dwivedi C: Sarcophine -diol, a chemopreventive agent of skin cancer inhibits cell growth and induces apoptosis through extrinsic pathway in human epidermoid carcinoma A431 cells. Translational Oncol 2009, 2:21-30.

31. Zhang X, Chen W, Guillermo R, Chandrasekher G, Kaushik RS, Young A, Fahmy H, Dwivedi C: Alpha-santalol, a chemopreventive agent against skin cancer, causes G2/M cell cycle arrest in both p53-mutated human epidermoid carcinoma A431 cells and p53 wild-type human melanoma UACC-62 cells. BMC Res Notes 2010, 3:1-15.

32. Bannon JH, Fichtner I, O'Neill A, Pampillon C, Sweeney NJ, Strohfeldt K, Watson RW, Tacke M, Mc Gee MM: Substituted titanocenes induce caspase-dependent apoptosis in human epidermoid carcinoma cells in vitro and exhibit antitumour activity in vivo. Br J Cancer 2007, 97:1234-1241.

33. Yoshida J, Ishibashi T, Nishio M: Growth-inhibitory Effect of a Streptococcal Antitumor Glycoprotein on Human Epidermoid Carcinoma A431 Cells: Involvement of Dephosphorylation of Epidermal Growth FactorReceptor. Cancer Res 2001, 61:6151-6157.

34. Masui H, Castro L, Mendelsohn J: Consumption of EGF by A431 Cells: Evidence for Receptor Recycling. J Cell Biol 1993, 120:85-93.

35. Harper JW, Elledge SJ, Keyomarsi K, Dynlacht B, Tsai LH, Zhang P, Dobrowolski S, Bai C, Connell-Crowley L, Swindell E, Fox MP, Wei N: Inhibition of Cyclin-dependent Kinases by p21. Molecular Biology of the Cell 1995, 6:387-400.

36. Lee DH, Szczepanski MJ, Lee YJ: Magnolol induces apoptosis via inhibiting the EGFR/PI3K/Akt signaling pathway in human prostate cancer cells. J cell biochem 2009, 106:1113-1122.

37. Kuo DH, Lai YS, Lo CY, Cheng AC, Wu H, Pan MH: Inhibitory effect of magnolol on TPA-induced skin inflammation and tumor promotion in mice. J Agric Food Chem 2010, 58:5777-5783.

38. Hartwell LH, Kastan M: Cell cycle control and cancer. Science 1994, 266:1821-1828.
39. Li W, Sanki A, Karim RZ, Thompson JF, Soon Lee C, Zhuang L, MC Carthy SW, Scolyer RA: The role of cell cycle regulatory proteins in the pathogenesis of melanoma. Pathology 2006, 38:287-301.

40. Sherr CJ, Roberts JM: Inhibitors of mammalian G1 cyclin-dependent kinases. Genes Dev 1995, 9:1149-1163.

41. Chilampalli C, Guillermo R, Kaushik RS, Young A, Chandrasekher G, Fahmy H, Dwivedi C: Honokiol, a chemopreventive agent against skin cancer induces cell cycle arrest and apoptosis in human epidermoid A431 cells. Exp Biol Med, September 9.

42. Sun SY, Hail NJ, Lotan R: Apoptosis as a novel target for cancer chemoprevention. Natl Cancer Inst 2004, 96:662-672.

43. Martin SJ, Reutelingsperger C, Mc Gahon AJ, Rader JA, Shie R, LaFace DM, Green DR: Early distribution of plasma membrane phosphatidyl-serine is a general feature of apoptosis regardless of the initiating stimulus: inhibition by overexpression of Bcl-2 and Abl. J Exp med 1995, 182:1545-1556.

44. Tewari M, Quan LT, O'Rourke K, Desnoyers S, Zeng Z, Beidler DR, Poirier GG, Salvesen GS, Dixit VM: Yama/CPP3213, a Mammalian Homolog of CED-3, Is a CrmA-Inhibitable Protease That Cleaves the Death Substrate Poly (ADP-Ribose) Polymerase. Cell 1995, 81:801-809.

45. Ghobrial IM, Witzig TE, Adjei AA: Targeting Apoptosis Pathways in Cancer Therapy. CA Cancer J Clin 2005, 55:178-194.

46. Bowman T, Garcia R, Turkson J, Jove R: STATs in oncogenesis. Oncogene 2000, 19:2474-2488.

47. Williams JG: STAT signaling in proliferation and development. Curr Opin Genet Dev 2000, 10:503-507.

48. Pedranzini $L$, Leitch $A$, Bromberg J: Stat3 is required for the development of skin cancer. J Clin Invest 2004, 114:720-728.

49. Aaronson DS, Horvath CM: A road map for those who don't know JAKSTAT. Science 2002, 296:1653-1655.

50. Agarwal C, Tyagi A, Kaur M, Agarwal R: Silibinin inhibits constitutive activation of Stat3, and causes caspase activation and apoptotic death of human prostate carcinoma DU145 cells. Carcinogenesis 2007, 28:1463-1470.

51. Hsu YF, Lee TS, Lin SY, Hsu SP, Juan SH, Hsu YH, Zhong WB, Lee WS: Involvement of Ras/Raf-1/ERK actions in the magnolol-induced upregulation of p21 and cell-cycle arrest in colon cancer cells. Mol Carcinog 2007, 46:275-283.

52. Chen LC, Liu YC, Liang YC, Ho YS, Lee WS: Magnolol inhibits human glioblastoma cell proliferation through upregulation of p21/Cip1. J Agric Food Chem 2009, 57:7331-7337.

53. Lee SJ, Cho YH, Park K, Kim EJ, Jung KH, Park SS, Kim WJ, Moon SK: Magnolol elicits activation of the extracellular signal-regulated kinase pathway by inducing P27KIP1-mediated G2/M-phase cell cycle arrest in human urinary bladder cancer 5637 cells. Biochem Pharmacol 2008 75:2289-2230.

54. You Q, Li M, Jiao G: Magnolol induces apoptosis via activation of both mitochondrial and death receptor pathways in A375-S2 cells. Arch Pharm Res 2009, 32:1789-1794

55. Tanaka K, Asamitsu KUH, Iddamalgoda A, Ito K, Kojima H, Okamoto T: Protecting skin photoaging by NF-kappaB inhibitor. Curr Drug Metab 2010, 11:431-435.

\section{Pre-publication history}

The pre-publication history for this paper can be accessed here: http://www.biomedcentral.com/1471-2407/11/456/prepub

doi:10.1186/1471-2407-11-456

Cite this article as: Chilampalli et al:: Effects of magnolol on UVBinduced skin cancer development in mice and its possible mechanism of action. BMC Cancer 2011 11:456. 